\title{
Loss and Grieving: Selves between Autonomy and Dependence
}

\author{
HiLduR KALMAN
}

Spadar-Abdon is the talk of the town-"he acted worse than if he'd lost his wife" (Lidman 374, my translation). Abdon, a character in the heptalogy Jernbanan (The Railroad) that deal with the struggles, hopes and loves of poor farmers, and the colonization of northern Sweden, during the nineteenth and early 20th century, is grieving the death of his horse, Stina. His grief is made more bitter by the fact that he let himself be fooled into allowing her to pull such a heavy load that her heart failed. But is it possible to grieve incorrectly? This may be just a fictional example, but nevertheless: Isn't it only the person who has suffered it who can truly know the meaning of a loss?

Literature and everyday life present numerous examples of how grief is experienced as a tension between an individual's own feelings and what are recognized as socially acceptable or reasonable ways of mourning. For instance, an ethnological study focused on the ceremonies and expressions of emotion at funerals of homosexual men during the late $20^{\text {th }}$ century in Sweden, a period when many young gay men died of AIDS, reports that some of these funerals were described by observers as deviating from prevailing norms, as "spectacles," as more like weddings (Svensson 2007).

What makes for acceptable grieving does not seem to be at stake only in the case of nonnormative or socially unrecognized relations. A recurrent theme in the stories of surviving 
relatives in a Swedish ethnological study of grieving processes was that people around them seemed unable to cope with their grief and their ways of grieving (Lundgren 72, 78-80). The importance of being allowed to talk about the person who had died was not questioned, nor was the need to talk about the circumstances surrounding death and dying, yet the particular expressions of loss and grief often seemed to be diametrically opposed to people's expectations. Those expectations held that the grieving ought to have come to an end at some point, that there was a threshold the griever ought to have crossed.

How are we to understand such mismatches between a griever's more or less consciously chosen expression and enactment of grief and loss, and others' seeming lack of acceptance or acknowledgement? This article attends to the way grief and its expressions may fail to meet, and may sometimes thwart, social expectations, and aims to provide a picture of how grieving, and the re-creation of various aspects of the selves both of the survivor and of the deceased, occur and are conditioned in and by social context.

Thus, instead of considering what grief may be or to what extent grievers express the "right" emotions, I intend to analyze experiences of grieving, in particular the social conditioning of these experiences, from a phenomenological perspective, and to explore how various aspects of the self (selves) are changed and re-created in grieving. ${ }^{1}$

\section{The emotion of grief}

We often differentiate between what we perceive as the world as it is "in itself" and what could be called our affective surroundings - that is, what is meaningful and real only to us, for instance, when an object or individual begins to exist for us through desire or love, or is lost. However, as Maurice Merleau-Ponty has shown, our existence is essentially affective; that is to 
say, our feelings, moods, and emotions exist neither in isolation nor separate from other ways in which we experience the world (1989[1962], 154ff). Moreover, there is hardly any aspect of life more important as regards experiencing meaning and quality than our feelings and emotions. Thus, it is not surprising that most of the canonical Western philosophers-for example, Plato, Aristotle, Spinoza, Descartes, Hobbes, Hume - have all theorized feelings to some extent. ${ }^{2}$ Since the mid- $20^{\text {th }}$ century, philosophers' interest in emotions has experienced a revival. There are several streams of thought here, but I will primarily concentrate on the one that focuses on the contextual dependency of emotions, where emotional experience is seen as being formed through the dynamics of social interaction, and social context is seen as constitutive of emotional experience.

The kinds of feelings mentioned most often in philosophical analyses are emotions, thought to be relatively enduring in character, and to manifest themselves in a pattern over time in a person's life-in Wittgenstein's words: “Grief' describes a pattern which recurs, with different variations, in the weave of our life" $(1968,174)$. In addition to grief, philosophers have attended to emotions such as love, hope, and anger, which not only extend over time but also characteristically color much of one's experience. ${ }^{3}$ But, as Wittgenstein notes, the distinctive patterns that allow us to identify emotions are variable, and it is difficult to mark any natural or sharp boundaries between particular emotions and more mixed or transient feelings. For instance, grief can at times be expressed as anger, and hope can quickly turn into fear or grief (cf. Lundgren 48 ff.; Nussbaum 22). As Sue Campbell notes: “[m]any passions and feelings do not fit easily into the relatively tidy categories provided by the standard emotions, and it is the complexities and subtleties of people's emotional lives that should orient our approach toward emotion theory" (3). 


\section{(a) The aboutness and valuational aspects of emotions}

Like other emotions, grief is marked by its intentionality, its aboutness, its being directed towards an object (see Gordon; cf. Parkinson 8). The way in which an emotional experience is directed toward an object is by virtue of its content and meaning, together with appropriate enabling conditions. It is important to note here that this "someone or something" to which emotions are directed is an intentional object - that is to say: When one is grieving over a person one has lost, that person is both more and less than the actual concrete particular, but is rather the person as he or she appears to the one experiencing the grief. Merleau-Ponty elucidates this affective feature of our experiences in showing how our feelings and emotions are neither isolated, nor separate from other ways in which in which we experience the world. So, for instance, we do not separate the body from the person in the smile that meets us through the open door, in the hand that greets us, and it is also through our own bodies that we understand the gestures of the other, not through some act of intellectual interpretation. A smile and a relaxed gait is an expression of joy, as well as a way of being in a specific situation (Merleau-Ponty 1856). We convey messages in our way of living the body, in our "style," our way of walking and talking, and even in our way of making love and our ways of grieving. This style appears in a direct way in habits, movements, and ways of "dealing with situations" or being in interaction with other people and the environment (Merleau-Ponty 154-8, 327). It is also expressed in what we perceive, become aware of and how we orient ourselves in the world.

Discussing intentionality and experience, Edith Stein $^{4}$ noted that in "theoretical acts, ... the 'I' may fail to be aware of itself insofar as it becomes absorbed in the objects of its acts. In contrast, in feelings the 'I' is always present, and our emotions have a direct reference to both the subject and the object" (Borden 115; cf. Stein 98-99). Stein further notes that "in feelings we 
experience ourselves not only as present, but also as constituted in such and such a way" (99). In a similar vein, Martha Nussbaum claims that emotions contain even more than their intentional objects, as the aboutness of emotions is also something "more internal, and embodies a way of seeing" (27, italics added), that is, one's "active ways of seeing and interpreting" (28). Aboutness thus includes a perception of one's self and one's own life as well-for instance, while grieving, we often see ourselves as deprived, alone, etc. In other words, the valuational nature of our appraisals, as given in our emotional experiences, encompass and express something of and about our selves as well $\left(22\right.$, n.2). ${ }^{5}$ Further, according to Nussbaum, emotions are a kind of judgment of value, which may include ideas as well as opinions, convictions as well as religious beliefs. For this reason, emotions are also something we can enter into a dialogue with-as they may, for example, be felt to be more or less justified (46 ff.; 82-8).

\section{(b) Social construction of (emotional) experience and identity}

In her discussion of grief, Naomi Scheman (2011) relates a scene from the film Torch Song Trilogy in which Arnold, the gay protagonist, and his mother are both at the cemetery grieving their lost ones: Arnold, his lover; his mother, her husband. The mother is furious that Arnold seems to think that their losses are comparable, and that there might be a commonality between her mourning and his. Scheman asks what it would take to settle the dispute between these two, and with recourse to Wittgenstein's remark on grief as a pattern in the weave of our lives, she notes:

It is the background, the history, the context - and what we make of them - that make whatever is currently in Arnold's mind or heart ... grief ... We need, that is, to see in Arnold's life and in his world a pattern that we will take as relevantly similar to the pattern in his mother's life and world. (156-7) 
The social, however, is not just a context in which feelings and emotions are enacted and more legitimacy is given to certain emotional experiences than to others. Campbell argues that "the expression of feeling is the articulation of the personal significance of an occasion, often in communicative situations," and that the "response of others, then, can make a difference to the feeling formed in several ways, most notably, perhaps, by becoming a part of the occasions to which we are responding" (137). While resisting the framing of feelings as socially constructed, ${ }^{6}$ Campbell still describes the expression of emotion as relational, and argues that understanding "affective experience as meaningful requires an understanding of the communicative and interpretive circumstances, individual and political, in which such meaning is created" (139). Pointing to the value of non-linguistic resources for making sense of feelings, Campbell claims that even as our feelings may be difficult to communicate, there is no need to characterize them as metaphysically private. As there are various resources for expressing what we cannot give a name to, the expressiveness of feelings, she argues, does not hinge on their being named. In a similar vein, Minae Inahara (2012) discusses philosophers' prime example of what is taken to be metaphysically private and an essentially incommunicable experience, that is, pain. She notes that it may well be resistant to ready communication, but argues that this inability to describe is not just an inability to describe to others. In such cases, one is equally unable to describe the pain to oneself: one lacks the words.

Scheman and I have further theorized the expression of pain as well as that of feelings and emotions in a paper where we argue that "[e]xpression marks the middle ground," where an expression of feeling is "linked inwardly to the experiencing and outwardly to its acknowledgement" $(2012,38)$. We claim that feelings are expressed and accepted (or not) in social contexts, and an expression of feelings that is met with acceptance becomes a different 
feeling from an expression of feelings that is not acknowledged. A feeling's (possibly restrained or even suppressed) expression as well as its acceptance (or lack thereof) are thus constitutive parts that cannot be subtracted from what makes the lived emotional experience what it is. In other words, a feeling that cannot be expressed or fails to be acknowledged becomes another kind of feeling, another kind of lived emotional experience, compared to one that in its manifestation receives expected social acceptance. Thus, the grief of Spadar-Abdon in The Railroad, is made more bitter not only by the fact that he had been fooled to make the carthorse pull too heavy a load. It is also due to the lack of concern and respect from his fellow men for the labouring creature in life, as well the lack of respect for his loss and grieving of his working companion of many years.

If social context is constitutive in making an emotional experience what it is, by enabling or obstructing various kinds of experiences, then feelings and emotions are socially conditioned and constructed. In advancing a post-positivist realist theory of identity, Satya P. Mohanty stresses that "[t]here are different ways of making sense of an experience, and the way we make sense of it can in fact create a new experience" (34). Working from an example in Naomi Scheman's paper, "Anger and the Politics of Naming," he argues that it would be false to say that an

emotion is the individual's own "inner" possession and that she alone has "privileged access" to its meaning or significance ... Rather, our emotions provide evidence of the extent to which even our deepest personal experiences are socially constructed, mediated by visions and values that are "political" in nature, that refer outward to the world beyond the individual. (Mohanty 34)

Important to note here is that his claim that all experience, of which emotions offer the paradigm case, is socially constructed "does not make it [experience] arbitrary or unstable in advance" (38). Referring to Nussbaum's claim that emotions are judgments of value, and the ways in 
which we ourselves and others may enter into dialogue with our feelings, Mohanty points to how "[e]xperiences are crucial indexes of our relationships with our world (including our relationships with ourselves), and to stress their cognitive nature is to argue that they can be susceptible to varying degrees of socially constructed truth or error and can serve as sources of objective knowledge or socially produced mystification" (38). Taking as his point of departure Mohanty's claim that "experience is not self-evidently meaningful" but "rather partly constituted by social forces and by the very act of coming to understand it," William S. Wilkerson investigates the possibility of latent meaning in experience (251), connecting it to MerleauPonty's phenomenological claim that we must recognize ambiguity as a fundamental feature of human experience $(265$, n. $10 ; 276)$. Wilkerson claims that having a certain emotion "is not just an inner feeling but a whole style of being in the world," and that even as one is able to distinguish and classify certain of one's feelings as a specific kind of emotion "that is never the whole story of one's experience" (260). Indeed, this echoes James R. Averill's claim that "[p]eople attribute emotions to themselves, based on paradigms provided by the culture, and on their acceptance of, or attitudes toward, those paradigms," and that the attribution may even often be retrospective (93).

Our emotional experiences of grief and mourning are thus socially constituted in two ways. First, the values and ideals of society are inscribed in our way of living these experiences, through the ways in which we talk about them, and the ways in which they are "paradigmatically" represented within our culture. Second, they are constituted through lived life. As social conditions and cultural values are lived and managed by us, they become, so to speak, sedimented or laid down within us, becoming part and parcel of our experiences, (cf. 
Merleau-Ponty 130). Merleau-Ponty highlights the way in which the lived body encompasses and expresses its history and lived experience as well as its presently lived relation to the world:

It is no more natural, and no less conventional, to shout in anger or to kiss in love than to call a table "a table." Feelings and passional conduct are invented like words ... It is impossible to superimpose on man a lower layer of behaviour which one chooses to call "natural," followed by a manufactured cultural or spiritual world. Everything is both manufactured and natural in man, as it were, in the sense that there is not a word, not a form of behaviour which does not owe something to purely biological being - and which at the same time does not elude the simplicity of animal life, and cause forms of vital behaviour to deviate from their pre-ordained direction, through a sort of leakage and through a genius for ambiguity which might serve to define man. (189)

Social conditions are incorporated and can be seen in embodied habits-habits such as ways of expressing grief and mourning. Merleau-Ponty suggests that our habits, our personal style, our personal ways of seeing and experiencing, are formed like a fold in fabric (215), such that "the personal is a happening, an event on the moving surface of the anonymous, like a wave on the sea surface" (Heinämaa, 2003, 51 n. 35). The surface on which the wave occurs, or the fold is formed, is the anonymous body, which is the basis of our ability to see, hear, perceive, etc. The personal body inherits this ability, as it were, where lived experience shapes our perception. In this way past lived experience is partly constitutive of future experiences. Cultural "scripts" are thus embodied, too, such as the notions we have of grief and the way we "do" grief. There are different ways of making sense of experiences such as loss, where cultural "scripts," as part of what socially conditions our emotional experience and orientation and response towards loss, affect the way we make sense of that experience.

\section{Grief and thwarted social expectations}

In recent years several theorists, among them Judith Butler and Sara Ahmed, have investigated the political dimensions and implications of the emotions (Ahmed 10). With focus 
on the "aboutness" of emotions, as involving an orientation towards an object, a stance on the world, Sara Ahmed suggests emotions to be "crucial to the very constitution of the psychic and the social as objects" (10). Pondering how, by virtue of political constitution, some lives get to be acknowledged, including by being grieved, Judith Butler asks: "Who counts as human? Whose lives count as lives? And finally, What makes for a grievable life?" (20). And one answer to these questions is given by Ahmed:

Love has an intimate relation to grief not only through how the subject responds to the lost object, but also by what losses get admitted as losses in the first place ... So there is an intimate relation between lives that are imagined as "grievable," in Judith Butler's terms ... and those that are imagined as loveable and liveable in the first place. (130)

Ahmed's observation as to the importance of loss being connected to a life that is admitted as loveable and liveable in the first place comes forth in the examples of Spadar-Abdon grieving his horse and Arnold his lover, as their losses do not qualify according to the norms. In SpadarAbdon's case the reliance between creature and man established and nourished through years of labour, driving and pulling heavy loads of timber and goods on icy winter roads, is not recognised as qualifying a mourning that has similarities with the loss of near relatives. In Arnold's case the loss of his lover as the unique individual he was to Arnold, the man with whom he had been, and in many ways still was, in a loving relation, was not recognised. Grief here displays its thoroughly relational nature, with its affinity to love, as Arnold's relation and their shared life was not recognised as being as loveable and liveable as was the relation between his parents. In light of this, the emotional logic of some of the funerals studied by Svensson, which appeared to take on the form of a wedding, celebrating the love between the person who had died and surviving friends and close ones, becomes clear. Referring to the works of Ahmed and Butler on how the funeral ritual gives legitimacy to what counts as life and thereby to what 
qualifies as loss, Svensson claims that the expression these funerals took on can also be seen as a response "to the predominant norms' condemnation and obstruction of grieving" (240, my translation). Being able to clearly manifest the individual's chosen and lived life by way of the funeral made it possible to show both what life, and what person, was being mourned. Other funerals in Svensson's study expressed the incompatible, and irreconcilable, attitudes of relatives as opposed to those of close friends and partners, where the deceased's homosexuality and the life he had chosen were at stake. For instance, relatives at times chose only to recognize the "original" boy - the one before his life as homosexual — to such a degree that the life he had lived with friends and lovers was eliminated or made invisible. ${ }^{7}$ In this way, that shared lived life was not ascribed the value of being grievable.

Losing or grieving someone with whom one has had a socially non-accepted romantic or friendship relation leads to concealed and perhaps even invisible grief. In line with Scheman's and my reasoning, this is also a different, and much lonelier, feeling of loss than a feeling that is granted social acceptance and acknowledgment. Lack of acceptance - and the accompanying difficulty with or impossibility of articulating one's grief in a social context-may make this grief both deeper and more bitter. But what then are we to make of the fact that people seemed unable to cope with the grieving of surviving relatives in Lundgren's study $(72,78-80)$ ? The grieving individual might, for instance, notice how people would stop speaking and withdraw, or seem to think that he or she was talking too often and too much about the deceased, or cried too often and too much. Above all, the grievers had a feeling that others thought their grieving was lasting too long. At times, one and the same person even might experience quite contradictory expectations as regards expression of feelings. One woman who had suddenly lost her father said: "What seemed most provocative was acting normal, that was abnormal! When I was able to 
smile, that was unbecoming; when I cried, that was trying ..." (Lundgren 55). But to be someone's child or parent, husband or wife, is to be a kind of person in a kind of relationship that is commonly accepted as being both liveable and consequently grievable. To explore this mismatch between the grieving and their surroundings let us here briefly return to the aboutness of grief, and how it includes a perception of oneself and one's life.

According to Butler, "What grief displays is the thrall in which our relations with others hold us" (23). In loss our relational self is revealed, along with the way in which "the ties we have to others, ... constitute what we are, ... compose us" (22). She continues

if the attachment to "you" is part of what composes who "I" am ... then I not only mourn the loss, but I become inscrutable to myself. Who "am" I, without you? ... On one level, I think I have lost "you" only to discover that "I" have gone missing as well. At another level, perhaps what I have lost "in" you, that for which I have no ready vocabulary, is a relationality that is composed neither exclusively of myself nor you. (Butler 22)

These lines point us to how the loss of the other is not exhausted as "merely" being a loss of another. Butler unravels the ways in which it is not evidently clear what has been lost of the other, nor of oneself, nor the extent to which the "I" and the "you" can be perceived as separate, rather than as constituted in a relationality that might stand in need of being articulated. We are thereby given reason not only to look more closely at the relational self, but also at the importance of narrative in relation to loss and grieving.

\section{Loss and the self (selves)}

Several philosophers, feminist philosophers in particular, have criticized an individualistic view of the self, and have instead focused on how the self is formed in relation to others and is maintained in a social context (see e.g., Baier, Brison, Campbell, Code). Aspects of the self have been theorized as being interwoven, and as constitutive of each other, such as the 
embodied, the narrative, the relational, the autonomous, and the dependent self. Stress has been put on the fact that we are all born into community, mutuality, contingency, and dependence, and that we thus do not begin as an "I," but as a "you." In other words, the self emerges, is shaped and re-shaped, in the relations we have with other people-relations in which we are both independent of and socially dependent upon each other. The prime example of independence is the one that is articulated in the most important dependence relation of all - the one we have to our parents. Independence, that is, is not an ontological given, but a relational achievement: the self, in other words, is relational, and even the autonomous self is articulated in relations. These accounts of relational selfhood suggest that we have joint responsibility for each other regarding what kind of meaning we can ascribe to our inner lives and our feelings, and for the ways in which we can appear and be intelligible to others and even to ourselves (cf. Scheman 1993, 52; Wilkerson).

\section{(a) Self and not-self?}

Understanding both the self and emotions as fundamentally relational raises questions about the experiences of those who survive the loss of someone with whom their feelings and identity were closely entwined. There is something absolute and obvious about death; it marks a point in time after which an embodied person ceases to exist. Moreover, it is primarily here that the idea of an absolute division between self and not-self, between death for the deceased and (continued) life for surviving relatives, makes sense. Something of this division was also reflected in the expectation placed on surviving relatives in Lundgren's study - the expectation that their grieving should at some point come to an end, and that the person who has died should be left on the other side of this absolute point in time. This figure of thought - which contains what would seem to be an absolute division between life and death, between the person who is 
still living and the person who has died - is a recurrent theme in Joan Didion's personal narrative The Year of Magical Thinking. With time, Didion also comes to express a need to let the dead be dead: "if we are to live ourselves there comes a point at which we must relinquish the dead, let them go, keep them dead" (225 ff.). Didion describes her inability to accept the fact that her husband has died and asks herself if this is because she could not understand that it was something that had happened to him. She wonders further if it is because she (still) understood his death as something that had happened to her, and she reproaches herself repeatedly in the book for what would seem to be her inclination to feel sorry for herself. The question of selfpity, raised by Didion, is interesting. Among other things, it indicates an absolute division: you are alive, the other is dead; there is no room for self-pity when, comparatively speaking, you are "the lucky one." Life goes on, but in a different way, as Didion expresses in a line written down early on: "You sit down to dinner and life as you know it ends" (77). But clearly, there are other aspects of the self than the embodied sense of either being alive or dead. As a 29-year-old widow reflected: "He took a pretty big part of me with him, somehow everything became very empty" (Lundgren 48).

Let us consider the notion of the surviving relatives, or, more generally, the survivors. It refers not just to the fact that some continue to live, but literally means that they have outlived the deceased (from the Latin supervivere) - that they are living after the death occurred, which is seen in relation to what existed before. After and before here constitute each other's prerequisite and implicit background. Being a survivor points to something that existed before, and this ascribed identity does not point to death. It takes its implicit point of departure from, and points to, life as it was and relations as they were before the loss. 
What is the connection between "before" and "after" the rupture of death? There is the self as a (changeable) narrative, and a life narrative that affects and is affected by our emotions. We are dependent on each other as listeners willing to listen to the changing narratives of our lives, about who we are, who we have been and wish to be, and what we have gone through. But there are always conditions for what stories we can tell about ourselves, and there are conditions for listening. There are also more or less "permissible" narratives-more specifically, there are normative expectations both for the life story as a narrative and for the logic of emotional narratives (cf. Nussbaum, 238-48). In particular, there are norms for grief, not just for how it should be manifested, but also for socially (more or less) accepted narratives of loss and grieving, as these are objects of social regularization and negotiation.

When you have lost someone, the loss and grief, and the events that provoked these feelings, need to be incorporated into your life narrative. But the course of the narrative changes not only with reference to the moment of loss and what comes after it, not only in terms of the here and now, but also in terms of the previous there and then. As the feeling of loss is added to one's perception of what was once a shared life and life-world, filled with recurring moments of reciprocity and synchronicity, shared habits, and moments of joy and sorrow, the redrawing past, the there and then, will be seen in new light. And as the lived relationality of one's earlier life changes, the understanding of one's self may change as well. 


\section{(b) Loss and the relational self}

As social beings we live in a field of tension between autonomy and dependence, and in cases when autonomy is articulated (as a lived identity) after we have lost someone, this can hardly be done without being grounded in the dependence in which we once lived. To this extent, most acts of grieving depicted in Lundgren's study are set within generally accepted norms. But those who were thought to grieve too long and too much continue-through their conspicuous mourning - to articulate and reveal themselves before others as having an affinity with the deceased while at the same time being deprived of him or her. Perhaps without this clarity, grievers feel they are at risk — like the deceased — of being made invisible as the individuals they are and continue to be. The new social identity in which they stand alone, and thus appear to be independent by definition, can be articulated only vis-à-vis the particular others whom one has earlier been dependent upon.

I see this articulation - which makes visible not only the loss of a loved one but also those parts of the self that were articulated in the now (partially) ended relation-as a way of establishing and re-establishing one's self and identity. We both take things along and leave them behind, with the help of empathetic others. And here is where the importance of both the narrative and the embodied comes in. It is a question of being able to see and make visible, to listen and tell—about what has been and what is now, about who we were and still are, about who we were but are no longer, about what we were and what we are now, such that the present (and always) autonomous self is articulated in relation to the previous (and always) dependent self. Further, it is not unusual for someone grieving to want new people, that is, persons who did not know the deceased, to "enter into" the relationship the griever has with the one being grieved. This might entail wanting the people that are in their life now to know the person who 
has been lost, for the dead to be real to them, and for the griever thereby also to be known as someone's daughter, son, lover or spouse.

The relational self may need to incorporate the grief, and even incorporate the person or thing one has lost. The significance of the other can sink in and be a part of one, like a pillar that always remains, and that one can lean against. Alternatively, it may be a question of needing to 'ex-corporate' the person/thing one has lost, where the barbs that remain in the flesh must all, one after the other, be painfully withdrawn from a self that is partially what the self was in the other, for the other, and that is thereby also the selffor oneself.

Such a hope for a continued relation is clearly expressed in an interview in a daily newspaper with a man who describes how the people around him, with the best of intentions, try to get him to "rebound" and "stop burying himself" after the death of his son, Svante. But he says that he "maybe doesn't want to be 'normal' again. That a normal life without Svante is not a life he wants. He lives with Svante inside him” (Nordgren 12, my translation; cf. Lundgren 77 ff.). He feels that many people, even professionals, think his way of thinking and feeling about his son's death is wrong, and that they want to portray it as a kind of illness. "But they cannot know what it's like for me ... I want to survive to be able to think about Svante. I'm living in something that I had no idea even existed" (Nordgren 12). He is living with Svante, and does not seem to be referring to an otherworldly dimension, but rather to a social dimension where the one that has been lost to death still lives on. The father wants to continue living in order to, among other things, think about his dead son, and in that way live with him. Similarly, some of the actions of grieving might be interpreted as devoted to continuing to re-establish and reshape the person who has died as well as our relation to him or her-and the part of our self that has had its life in the other. 
This kind of re-establishing and reshaping may even fit into other people's expectations - although such behaviour is expected to play a less important role as time passes. The social expectation seems to be that the griever should recover from mourning, and thereby leave the deceased behind. The father above, however, shows clearly that he wants his son to remain a part of his life-where his recovery might rather be described as living in a creative work and state of mourning. But as his thoughts and feelings are not met with sympathy, he has, to a certain extent, ended up outside community, instead of continuing to be, also in relation to others, Svante's father.

In rituals surrounding death, there is often an underlying figure of thought, according to which these rituals have a function in the grieving process - the function being to help people end their relation to the person who has died. During recent years, however, emphasis has been put on the notion that there is value in continuing the social relation to the deceased, and that this relation can be said to be lasting, but changed (see, for example, Hadders; Lundgren 148 ff.; Silverman \& Klass). But in what ways can we engage in social relations with someone who has died? A short story by Lajos Zilahy illustrates this theme. The short story tells of how a tired and ailing 35-year-old carpenter, János Kovács, finishes his working day, goes home, eats though he's not hungry, only to die in the middle of the night in the shabby room he rents. But the story doesn't end here: by and by we learn how a human being can be said to remain after death, among other things in the objects he or she has created, but primarily in the thoughts, speech, and stories of, as well as the loss felt by, the living.

Many people who have lost someone are familiar with this. When the acute and painful grief has subsided, and calm eventually ensues, many discover that it is only the loved one's body that is irrevocably gone. Those who have been part of our lives are still there-they appear 
in our memories, our speech and our stories. At times I hear a joke and think, "Papa would have like that!" But this is not just a question of remembering. On the contrary, eventually I have come to think that this is not just a joke that my father, who has been dead for more than 30 years, would have liked, but that there is a part of me that cannot be separated from the way in which he would have laughed at that joke. It is part of my way of listening, a part of my way of enjoying the joke. When I recognise something as, in phenomenological terms, inviting, calling on me, as a joke, as being funny - there is no way to separate or distinguish this emotional experience from me, as it is I who perceive this "call" now, along with a felt affinity between me and my father. In this respect, we live our lives surrounded by the living, but also by the deadwe are part of each other, and thus can be said to live our lives in each other. But note here, how natural it is for me to refer to myself as being my father's daughter-we are expected to be shaped by our parents-but much less so, to have it accepted as natural for the man in the interview to remain Svante's father, or for someone to remain someone's lover.

\section{(c) The self as narrative and loss}

By continuing to articulate an affinity with and dependence on the person we have lost, we create and re-create both our own self and the other's self. Given the notion of an absolute division, such re-creation may be easiest to understand in terms of narrative aspects, such that kinship and mutual dependence as well as loss and grief are articulated and incorporated in the life narrative. Those aspects of the self that are formed in relation to others-and that are maintained by the social context of which we are a part - can, in some sense, be said to live on after death. Talking about those who used to live with us recalls them to life; they continue to participate in the stories we tell and are, thus, a part of us - their survivors. 
Merete Mazzarella has pursued similar lines of thought on how the past- "which once was just as manifestly real, just as sensually concrete as our present-is irrevocably lost," at the same time as it - in its "sensual manifestness - can live on" in our narration and our narratives "thanks to our sense of loss" (Mazzarella, "The Tale Preserves", 2, my translation). She also points out that memory, as the English word "re-member" lets us understand, is connected to reshaping, and that narration is connected to re-establishing. After all is said and done, a person who has lived with us can still participate in our lives, be a part of us.

Some of the surviving lovers, friends, and partners we meet in Svensson's dissertation risked, on top of losing a loved one, not being allowed to express their grief in a context where grief is given a common, accepted meaning, that is, at the funeral. In this way, it was not only their grief that was made invisible and erased, but also their life — a life they shared "before" and that they were continuing to live now. By portraying themselves emphatically as both survivors and partners through the funeral's chosen emotional expression, the funeral became an alternative and life-affirming narrative, by which a grievable life and the loss were made visible.

To the extent that parts of our previous self have been lost in the loss, we need those parts of the self that have survived, as well as those that were lost, to be known and acknowledged. Thus, it is not merely grief that "requires" acceptance, but also the grievers as subjects, who can create themselves anew on the basis of this grieving self.

\section{The social organization and control of mourning}

Naturally, feelings of grief are not just a matter of making one's grief visible; such feelings also need to be socially acknowledged and received. Interestingly enough, though, the examples from Lundgren's study are about loss and grief in relations that are regarded as socially 
accepted. Relatively speaking, the grief of these people already has a social context in which to be expressed. Nevertheless, they shared certain experiences with others who grieved losses in socially less accepted relations. How are we to understand this lack of acknowledgement when it cannot be put down to the lack of acceptance of the relations that were there prior to the loss?

It seems to be the case that grieving today is expected to be a transition, a process through which one moves from one life phase to another, and through which one recovers from mourning. Those who do not recover from mourning according to this social norm are seen as "problematic" cases that display a kind of "dysfunctionality." This dysfunctionality is ascribed to grievers who are not considered to have completed their grieving process in the right way. Thus "functional grieving" is supposed to help the griever move on, and thereby stop grieving.

Ian Craib observes a change in what he calls "the social organization of mourning," a change that carries a risk for the pain and loss to be denied. He recognises several social processes to be at work, one of which is the disappearance of socially-approved mourning rituals, to the extent that "the bereaved are ignored, or expected to be back in normal life as soon as possible" (Craib 157). He suggests part of an explanation to be a sequestering of death, grief, and mourning in our society, so that they have become split off from the rest of our life and given their own specialized place governed by experts, where the psychiatric, therapy, and counselling professions in different ways "have attempted to establish control over mourning" (Craib 158). He argues that practices and ideas that might be benign and helpful in the consulting rooms for some may have quite another effect in the wider culture of Western society. Such practices and ideas are there at risk of becoming caught up in a process of social control, where "the sort of personality that is most suitable to contemporary society" is being produced (Craib 158), and where the "job becomes getting the machine back on the road" (Craib 164). Craib claims that the 
"taming of grief" has been at the cost of understanding the real complexities of grief and mourning, "its individuality and the ... way in which a person finds his or her own way through it, to a different life or to their own death — or to the ... way in which they might decide not to move on from mourning" $(163,166)$. It seems that an uncomprehending world's expectations of what should be happening in grief work as a form of social control, by which grieving might even be obstructed, thwarting the griever's attempts to discover, and re-create, what has been lost, in all its ambiguity and complexity.

During recent years, I have noticed what seems to be an increased number of "grief notices" in Swedish daily papers containing text such as "one year of loss," "two years of loss," etc. In Sweden today, the practice of wearing black clothing or a mourning band has become less and less common. Such visible and socially accepted manifestations of grief have not as yet been replaced by other practices that serve the same, simple purpose. Instead there is mostly silencewhich the survivors in Lundgren's study felt the need to break, to be able to talk about the person who has died, to make their loss and their grieving (self) visible and thereby acknowledged. Some other survivors (but definitely not the majority) have, according to my observation, though, decided to show their continued grief by placing a notice in the newspaper. If no one else talks about the person one has lost, then one tries to make that loss visible, to articulate the experience of grieving in order to recreate one's self (selves), even as one may be met by resistance or lack of acknowledgement.

\section{Grieving and re-creation of selves}

The experiences of grieving explored here can be said to manifest a difference between the social expectation of recovery from mourning, and an active, maybe even hopeful, 
anticipation of recovery in and through a creative work of mourning, in terms of a re-creation of social selves. This process includes both one's own self and, in a different way, the selves one has lost, in a field of tension between autonomy and dependence vis-à-vis the person one has lost. Just as autonomy is articulated in relations of dependency, the mourners discussed in this paper were able to articulate their bereft selves only by remaining connected to their previous lived relations. For them, the dead continue to live with the bereft griever, such that the one who lives on is allowed to re-create his or her self and his or her relation to "you," in a narrative and a social context where "what remains of the wholeness one lived in" does not just become "an incomplete remnant, the meaning of which is difficult to identify" (Lundgren 37, my translation). Thus, the felt mismatches between expressions of grief and their lack of acceptance points us to the importance of acknowledging grief in order for the griever to be able to re-create his or her self in such a way that the person who has died does not disappear from the social world.

Our self, the social self, is essentially dependent on others. Recognizing the scope of this dependence involves both moral and political dimensions, as shown in the works of Ahmed, Butler, Craib, Scheman, and Wilkerson, among others. Failing to recognize our fundamental dependence on other people - in this case the dependence of those who are grieving the deceased as well as on varyingly empathetic or accepting others - masks the power of the surrounding world. In the words of María Lugones, "[w]e are fully dependent on each other for the possibility of being understood and without this understanding we are not intelligible, we do not make sense, we are not solid, visible, integrated; we are lacking" (424). As long as we remain within the socially expected, this field of power and dependence can be difficult to catch sight of. But when we, or others, do not seem to fit in, it is easier to see that even things we experience as most intimate and private, such as our feelings and identity, largely lie in the hands of others. 
Grieving, as re-creation of the self, is conditioned in and by social context, whether or not grievers experience problematic mismatches and failures of acknowledgment. It is important to keep in mind that there are highly individual ways to grieve and mourn, and that responses to loss are complex. But even in this individualized complexity, we constitute one another's sense of what selves, what lives, and what feelings are possible.

\section{Notes}

${ }^{1}$ To use the word "through" here would probably sound more natural, but it carries the implication of a causal, rather than a constitutive, relationship. The slight unnaturalness of "in" helps to make the point I want to make.

${ }^{2}$ For an overview of philosophical research on emotions, historical as well as thematic, see de Sousa.

${ }^{3}$ The distinction between feelings and emotions should be seen in the contexts in which it is made, that is, in an analytical context where one has defined and tried to explore larger and more coherent phenomena. However, a discussion of how, and with what degree of success, such a delimiting distinction is possible to make is not relevant to the focus of this article. In the present text, I use both terms to improve readability through variation, but I also use the analytically distinctive concept emotion throughout when I adhere to another author's conscious choice. As de Sousa points out it is increasingly common to use the terms feelings and emotions interchangeably (17).

${ }^{4}$ Stein argues that our experience is intentional, but in contrast to other philosophers here cited, regards emotions as having essential structures (Borden, 114). In my discussion of Stein's work I am are drawing most directly on Borden's discussion of Stein's longer, more detailed and complicated account.

${ }^{5}$ The valuational aspect of emotions is given weight by Stein as she describes our emotions as being motivated by the perception of value, indeed that our emotions are responses to value (Borden, 38-39).

${ }^{6}$ She does so by portraying and arguing against a strong version of social constructivism, by which "affective meaning is social meaning" (Campbell 137), and where social meaning is "determined by shared rules, conventions, norms, and so on" (139, italics added). She claims that constructivists "confuse the private, in the sense of epistemologically private, with the 
legitimately personal" (139). But there are other varieties of social constructionism that do not hinge on such strong claims, which will be developed further on in this paper.

${ }^{7}$ This choice of framework could give an added, albeit unintended, ironic dimension to the pursuit of authenticity expressed in one often-used phrasing in Swedish death notices: "In our memory we see you exactly as you were" (see Svensson 90 ff.).

\section{Works Cited}

Ahmed, Sara. The Cultural Politics of Emotion. Edinburgh: Edinburgh University Press, 2004.

Averill, James R. "The Social Construction of Emotion: With Special Reference to Love." The Social Construction of the Person. Eds. K. J. Gergen and K. Davis. New York: Springer, 1985. 89-109.

Baier, Annette. Postures of the Mind: Essays on Mind and Morals. London: Methuen, 1985.

Borden, Sarah. Outstanding Christian Thinkers: Edith Stein. London: Continuum, 2004.

Brison, Susan J. "Outliving Oneself: Trauma, Memory and Personal Identity." Feminists Rethink the Self. Ed. Diana Tietjens Meyers. Boulder, CO: Westview Press, 1997. 12-39.

Butler, Judith. Precarious Life: The Powers of Mourning and Violence. London: Verso, 2004.

Campbell, Sue. Interpreting the Personal: Expression and the Formation of Feelings. Ithaca, NY: Cornell University Press, 1997.

Craib, Ian. Experiencing Identity. London: Sage Publications, 1998.

Code, Lorraine. "Second Persons." Science, Morality \& Feminist Theory. Eds. Marsha P. Hanen and Kai Nielsen. Calgary: University of Calgary Press, 1987.

de Sousa, Ronald. "Emotion." The Stanford Encyclopedia of Philosophy (Spring 2012 Edition). Ed. Edward N. Zalta. Web. 22 March 2012.

Didion, Joan. The Year of Magical Thinking. London: Fourth Estate, 2005.

Gordon, Robert M. “The Aboutness of Emotions." American Philosophical Quarterly, 11, no. 1 (January, 1974): 27-36.

Hadders, Hans. "Between the Living and the Dead." European Journal of Palliative Care, 8 (2001): 160-162. 
Heinämaa, Sara. Toward a Phenomenology of Sexual Difference. Lanham, MD: Rowman \& Littlefield, 2003.

Inahara, Minae. "The Voice of Pain: The Semiotic and Embodied Subjectivity." Embodied Selves, Eds. Stella Gonzalez-Arnal, Gill Jagger and Kathleen Lennon. London: Palgrave Macmillan, 2012. 180-195

Kalman, Hildur and Naomi Scheman. "Inflecting Pain: Expression, Acknowledgement, and Interpersonal Space." At the Edge of Being: The Aporia of Pain. Eds. H. McKenzie, J. L. Quintner and G.A. Bendelow. Witney: Inter-Disciplinary Press, 2012. 37-46.

Lidman, Sara. Jernbanan [1] (The Railroad). Stockholm: Bonnier, 2003.

Lugones, María. "Playfulness,'World'-travelling, and Loving Perception." Women, Knowledge, and Reality: Explorations in Feminist Philosophy, 2nd ed. Eds. Ann Garry and Marilyn Pearsall. New York: Routledge, 1996. 419-33.

Lundgren, Britta. Oväntad död - förväntad sorg: en etnologisk studie av sörjandets processer (Unexpected death-expected grief: an ethnological study of grieving processes). Stockholm: Carlsson, 2006.

Mazzarella, Merete. "Berättelsen bevarar det förflutna" (The Tale Preserves the Past). Dagens Nyheter (Stockholm), 7 August 2003, sec. Kultur, p.2.

Merleau-Ponty, Maurice, Phenomenology of Perception, Routledge, London, 1989[1962].

Mohanty, Satya P. “The Epistemic Status of Cultural Identity: On Beloved and the Postcolonial Condition." Reclaiming Identity: Realist Theory and the Predicament of Postmodernism. Eds. Paula M.L. Moya and Michael Roy Hames-Garcia. Berkeley: University of California Press, 2000. 29-66.

Nordgren, Malin. "Sorgen var inget problem som gick att lösa." (The mourning was not a problem that could be solved.) Dagens Nyheter (Stockholm), 23 January 2001, sec. B, p. 12.

Nussbaum, Martha Craven. Upheavals of Thought: The Intelligence of Emotions. Cambridge: Cambridge University Press, 2001.

Parkinson, Brian. Ideas and Realities of Emotion. Florence, KY: Routledge, 1995.

Scheman, Naomi, "Forms of life: Mapping the Rough Ground." Shifting Ground: Knowledge and Reality, Transgression and Trustworthiness. Oxford: Oxford University Press, 2011.

- "Individualism and the Objects of Psychology." Engenderings: Constructions of Knowledge, Authority, and Privilege. New York: Routledge, 1993 [1983]. 36-53. 
- "Anger and the Politics of Naming." Engenderings: Constructions of Knowledge, Authority, and Privilege. New York: Routledge, 1993 [1980]. 22-35.

Silverman, Phyllis R. and Dennis Klass. "Introduction: What's the Problem?" Continuing Bonds: New Understandings of Grief. Eds. Dennis Klass, Phyllis R. Silverman and Steven L. Nickman. London: Taylor \& Francis, 1996. 3-26.

Stein, Edith. On the Problem of Empathy. 3rd rev. ed. Washington, DC: ICS Publications; 1989.

Svensson, Ingeborg. Liket $i$ garderoben: en studie av sexualitet, livsstil och begravning (The body in the closet: A study of sexuality, lifestyle and burial). Dissertation. Stockholm University, Stockholm: Normal, 2007.

Wilkerson, William S. "Is There Something You Need to Tell Me? Coming Out and the Ambiguity of Experience." Reclaiming Identity: Realist Theory and the Predicament of Postmodernism. Eds. Paula M.L. Moya and Michael Roy Hames-Garcia. Berkeley: University of California Press, 2000. 251-78.

Wittgenstein, Ludwig. Philosophical Investigations, 3. ed., repr., Oxford: Blackwell, 1968.

Zilahy, Lajos. "När dog János Kovács?” (When did János Kovács die?) Trans. from Hungarian to Swedish by Nils-Herman Lindberg. Hjärnstorm, no. 56-57 (1996): 45-6. 